\title{
LAAJASTI TYÖVÄENTUTKIMUKSEN TIIMOILTA
}

Vuosina 2007-2012 toimin viidesti tämän julkaisun päätoimittajana. Se oli antoisaa aikaa. Tehtävä oli mieluinen sekä tärkeä, ja työskentelyilmapiiri toimituksessa erinomainen. Oltuani sen jälkeen kuusi vuotta toimituksen rivijäsenenä saatoin havaita siltäkin paikalta, että sama meno jatkui. Palattuani nyt jälleen päätoimittajaksi professori emeritus Seppo Hentilän, julkaisumme ensimmäisen professori-päätoimittajan jälkeen, koen tehtävän entistäkin velvoittavammaksi. Julkaisumme on viimeiset puolitoista vuosikymmentä vahvistanut kaiken aikaa asemaansa maamme ainoana työväentutkimukseen suuntautuneena, eri tieteenalat kattavana aikakauskirjana, joka samalla on julkaisijansa tärkein tuote ja käyntikortti. Samalta pohjalta jatkamme. Kuluvana vuonna olen kiitollisena havainnut, että myös toimituksen ilmapiiri on ennallaan. Yhteistyö toimii oivallisesti.

Lukijan käsillä olevan vuosikirjan teemana on Vuosi 1919 - uusi alku. Sisällissodan jälkeen työväenliike oli maahan lyötynä, mutta vuonna 1919 alkoi tapahtua. Pitkin maata suljettuina olleet työväentalot avattiin jälleen, ja työväenjärjestöt pääsivät jatkamaan työtään. Niin teki myös kymmenen vuoden ikään ehtinyt Työväen Arkisto. Lisäksi työväenliikkeen sisällä tapahtui merkittävää itsenäistymistä porvarillisesta järjestömaailmasta, kun Työväen Sivistysliitto (TSL) ja Työväen Urheiluliitto (TUL) aloittivat. Vuoden 1919 eduskuntavaaleissa sosialidemokraatit olivat mukana ja saavuttivat jälleen suurimman puolueen aseman. Tässä julkaisussa huomion kohteena ovat mainitut kaksi järjestöä. Maisterit Elina Hakoniemi ja Tero Tuomisto valottavat eri näkökulmista TSL:n alkuvaiheita. Professori emeritus Seppo Hentilä tarkastelee puolestaan pitkällä aikajaksolla TUL:n vaiheita. Professori Hannu Itkonen sekä tutkijat Pertti Matilainen ja Anna-Katriina Salmikangas valotta- vat tutkimusta TUL:n seurojen näkemyksistä ja pohdiskelevat työväenurheilun tutkimuksen tilaa. Näiden artikkeleiden lisäksi tarjolla ovat professori Pauli Kettusen laaja tarkastelu eturistiriitojen ja suunnittelun merkityksestä Mauno Koiviston yhteiskuntapolitiikassa sekä oikeustieteen tohtori Marianne Vasara-Aaltosen artikkeli, jossa hän havainnoi työväenliikkeen ja oikeusaputoiminnan suhteita 1900 -luvun alussa.

Vuonna 2008 julkaisumme sisältöön mukaan ottamani Keskustelua-osion palstoilla on vuosien varrella julkaistu lukuisia, ajatuksia herättäviä puheenvuoroja. Myös tällä kertaa osion sisältö on mitä kiintoisin. Vuosikymmenen vaihteen jälleen lähestyessä on aika pohtia työväentutkimuksen uusia haasteita runsaan vuoden päästä alkavan 2020-luvun kynnyksellä. Professorit Anu Lahtinen, Pirjo Markkola ja Hannu Itkonen pohtivat kysymystä erinomaisissa puheenvuoroissaan eri näkökulmista. Kuten jo osion ensimmäisessä, Matti Hannikaisen puheenvuorossa vuonna 2008, myös tämänkertaisissa puheenvuoroissa nousee esiin Työväen historian ja perinteen tutkimuksen seuran huomattava merkitys työväentutkimuksen edistäjänä.

Graduesittelyt kertovat tuttuun tapaan muutaman esimerkin voimin, että työväentutkimus on vahvasti esillä opiskelijoiden mielissä heidän valitessaan opinnäyteaiheitaan. Kirjaarvio-osio, tärkeä osa julkaisuamme, on jälleen runsas ja monipuolinen kattaus kuluneen vuoden runsaasta työväentutkimuskirjallisuudesta. Kuten ennenkin, työväen perinnejärjestöt kertovat vuosikirjan päätteeksi monipuolisesta toiminnastaan kuluneena vuonna.

Toivotan lukijoille kiintoisia lukuhetkiä julkaisumme parissa ja miellyttäviä Joulun pyhiä!

\section{Erkki Vasara}

päätoimittaja

erkki.vasara@ helsinki.fi 